The 3rd International Conference on Biological Science 2013

(The 3rd ICBS-2013)

\title{
DRY-FIELD (TEGALAN) AGROFORESTRY SYSTEMS AS MINIATURE NATURE FOREST IN OUTSIDE FOREST AREA ON BULU - GIRIPURWO VILLAGE, GIRIMULYO DISTRICT, KULONPROGO
}

\author{
Chandra Nur Triwiyanto ${ }^{1}$, Priyono Suryanto ${ }^{2}$, Budiadi ${ }^{2}$ \\ ${ }^{1}$ Research assistants of Forestry Faculty UGM, Yogyakarta (anttoindra@yahoo.co.id) \\ ${ }^{2}$ Lecture of Forestry Faculty UGM, Yogyakarta (psuryanto@yahoo.com)
}

\begin{abstract}
A dry-field (tegalan) is one of the subsystems of classical agroforestry, where there is no intensive management of both the spacing and the selection of the type that is considered. Dry-field (tegalan) agroforestry subsystems have a state that resembles natural forest ecosystems. It became an opportunity execution of research related to the stands composition of dry-field (tegalan) and forest nature. The purpose of this study is to determine the pattern of developing agroforestry in Bulu and the relation of the natural forest. This research was conducted in Bulu-Giripurwo Village, Girimulyo District, Kulonprogo. Data was collected at 36 sample plots representing 3 strata. The first stratum had an area of $<1000 \mathrm{~m}^{2}$, the second $1,000 \mathrm{~m}^{2}-2,000$ $\mathrm{m}^{2}$, and the third $>2,000 \mathrm{~m}^{2}$. K-Means Cluster Analysis and exponential equation modeling was used to analyze the dry-field (tegalan). The results of this study indicate that there were three models of management of cultivated land in Bulu; the Mixed Model, Model MPTS dominant plants, and forest trees dominant model. Mixed models had the stand equation $Y=3.39 \times 2.7128^{-0,026 x}$ with an $R^{2}$ of 0.798 . The dominant MPTS plan models had the stand equation $3,155 \times 2.7128^{-0,021 x}$ with an $R^{2}$ of 0.770 . The dominant of forest trees models has stands equation $Y=3.182 \times 2.7128^{-0,024 \mathrm{x}}$ with $\mathrm{R}^{2}$ of 0.706 . These results demonstrate agroforestry modeling subsystem dry-field (tegalan) has characteristics resembling natural forest indicated from the value of $R^{2}$ that characterized so close with the equation of uneven-aged forest model.
\end{abstract}

Key words: Agroforestry, dry-field (tegalan), natural forest

\section{INTRODUCTION}

Planting trees outside the forest area has been known for a long time, but as the development of the times, it becomes interesting to study. The study of agroforestry as an integrated system of forest outside the forest area has addressed the expansion of economic and social functions of forests to support the existing ecological functions. In principle, agroforestry is an alternative solution to solve the environmental, economic, and social problems that are going on (Budiadi et al., 2012).

Agroforestry is growing by adjusting the communal characteristics called community forests. A community forest is a community-managed forest, both on private, communal, or customary land, as well as land owned by the state (Awang, 2001). Community forests play an important role, in addition to incentives to reduce deforestation and forest degradation in REDD+ schemes, community forests also serve as a first step to achieve sustainable forest management (Abrams et al., 2012).

The development of agroforestry late lead to marked changes in terms of utilization. Agroforestry transformed into a system of crop cultivation that leads to the production of the cropping pattern used is a monoculture. Agroforestry currently increasing growth and tends to depend on market demand, in other words towards an agroforestry planting monoculturebased production (Kumar \& Nair, 2006). Agroforestry refers to the development of production

ISSN 2413-0877 @ 2015 The Authors.

Published by KnowledgeE Publishing Services This is an open access article under the CC BY-NC-ND license (http://creativecommons.org/licenses/by-nc-nd/4.0)

Selection and Peer-review under responsibility of the 3rd ICBS-2013

Doi http://dx.doi.org/10.18502/kls.v2i1.145 
scale, there are indications will lose its ecological function.

Another study showed a pattern of agroforestry development on private forests is not referring to the purpose of production. Agroforestry management merely used as land cover and have a tendency as a traditional practice where the enrichment plant that was influenced by the availability of planting seeds and land area available. Land managers to plant a variety of plants and carried in large numbers in order to meet the land (Suryanto, 2012). According to Simon (2008), the lack of planning in agroforestry systems is a problem that needs to be solved in order to improve productivity and quality of results.

Bulu, which includes the village Giripurwo, Girimulyo District, Kulon Progo Regency, is a fertile area that is located in the Menoreh Mountains. Bulu is one of the places where the majority of the population has dry-field land with an agroforestry subsystem. Dry-field in Bulu has interesting characteristics, with the absence of the regular type of setting in the land and not the spacing, so that at a glance, dry-field resembles secondary natural forest. Secondary natural forests are known to have the characteristics of young stands with smaller trees of the primary forest, young age, and do not stand so close (Hardiwinoto et al., 2011). The characteristics of the dry-field at Bulu are interesting to study in order to understand the similarity between upland agroforestry subsystems and natural forests.

\section{MATERIALS AND METHODS}

The study was conducted in Bulu, Giripurwo Village, Girimulyo District, Kulon Progo Regency, Yogyakarta Province. Bulu is in the Menoreh Mountains. According to data from BP DAS Serayu Opaque Progo in 2012, the Menoreh Mountains have an annual rainfall average of $2,150 \mathrm{~mm} / \mathrm{year}$. The average temperature is $25^{\circ} \mathrm{C}$ and average humidity is $82.2 \%$. Topography of hills and mountains with an altitude of 500-1,000 meters above sea level, slope ranged between $15 \%-45 \%$. Desa Bulu is located in the Menoreh Mountains with a height of 800 meters above sea level. The study took place from March to December 2012. The study began with a survey to determine the location of the sample. The selection of samples was determined based on land area. The number of samples taken from 36 plots, with the census method used was $100 \%$ for each sample plot. The selection of 36 sample plots was based on a minimum number of samples is 30 normal samples (Kangas \& Maltamo, 2006). The selection of $100 \%$ based on the composition of the census compilers dry-field was very diverse in every land unit. Elections to facilitate further analysis of the discussion in agroforestry systems in the dry land sample were divided into 3 strata. Each stratum was repeated 12 times. Strata were based on land area. The stratum division was as follows: Stratum $1 \mathrm{had}$ a land area of $<1,000 \mathrm{~m}^{2}$, Stratum 2 had a land area of $1,000 \mathrm{~m}^{2}-2,000 \mathrm{~m}^{2}$, and Stratum 3 had a land area of $>2,000 \mathrm{~m}^{2}$.

Analysis of the data used in this research included K-means cluster, calculating the abundance of species, and a diameter class distribution model to find an exponential regression equation.

\section{RESULTS AND DISCUSSION}

\section{Agroforestry Mixture Model}

Mixed agroforestry patterns have a tendency vast land, with the average number of plants/ 
ha lower than the two other clusters. The number of plants could have been influenced by slope steepness and mean diameter in a forest area. Has a characteristic pattern of mixed agroforestry mean diameter of $>20 \mathrm{~cm}$, which means in the tree category. Condition can be interpreted in mixed agroforestry pattern has great LBDs (can be seen from the mean diameter) that affect stand density in an area of the region. The pattern of mixed agroforestry stands composition was relatively balanced between plants MPTS and forestry crops.

The profile of the K-means clusters by looking at the upper limit, lower limit, and the mean of each variable, may show the characteristic pattern of mixed agroforestry. Mixed agroforestry patterns have a tendency to land with an area of land with average characteristics who are in or are in stratum 3 (land area of $>2,000 \mathrm{~m}^{2}$ ), with a mean of $2084.57 \mathrm{~m}^{2}$ (Table 1). Patterns of agroforestry intervention had a mean number of plants/ha with a mean number of stem 1074.046 and $39.30 \%$ slope. The mean diameter of the pole and tree survival rate was $20.36 \mathrm{~cm}$ with a mean standard deviation of $7.75 \mathrm{~cm}$. The constituent of plant species composition was dominated by forest trees with a mean percentage of $53.25 \%$ while the mean percentage of $46.75 \%$ MPTS crop.

Table 1. Profile dry-field with mixed agroforestry patterns in Bulu.

\begin{tabular}{ccccccccc}
\hline $\begin{array}{c}\text { Patterns of } \\
\text { Agroforestry }\end{array}$ & $\begin{array}{c}\text { Broad } \\
\left(\mathrm{m}^{2}\right)\end{array}$ & N/ha & $\begin{array}{c}\text { Slope } \\
(\%)\end{array}$ & $\begin{array}{c}\text { Diameter } \\
\text { Average } \\
(\mathrm{cm})\end{array}$ & $\begin{array}{c}\text { Diameter Standard } \\
\text { Deviation } \\
(\mathrm{cm})\end{array}$ & $\begin{array}{c}\text { MPTS } \\
(\%)\end{array}$ & $\begin{array}{c}\text { Forestry } \\
\text { Plant } \\
(\%)\end{array}$ \\
\hline \multirow{2}{*}{\begin{tabular}{c} 
Mixed \\
\multirow{2}{*}{ Min }
\end{tabular}} & 602 & 578 & $9.00 \%$ & 18.940 & 6.035 & $22.73 \%$ & $34.14 \%$ \\
& Max & 3.955 & 2.558 & $60.00 \%$ & 22.669 & 10.721 & $65.86 \%$ & $77.27 \%$ \\
& Average & 2084.57 & 1.074 & $39.30 \%$ & 20.362 & 7.754 & $46.75 \%$ & $53.25 \%$ \\
\hline
\end{tabular}

Agroforestry had a mixed $R^{2}$ value of 0.798 . The constant value of $3.390 \mathrm{~K}$ and a constant value was $-0,026$. So we get an exponential equation for mixed agroforestry models:

$$
Y=3.39 \times 2.7128^{-0,026 X} \text { with } R^{2}=0,798 .
$$

The agroforestry interference pattern has a close structural composition and characteristics that most closely resembles a natural forest, in terms of the distribution of diameter classes compared with other agroforestry patterns in Bulu. The compositional structure shows similarities with the model of uneven-aged forest that has characteristics resembling a natural forest indicated by the $R^{2}$ value of 0.798 .

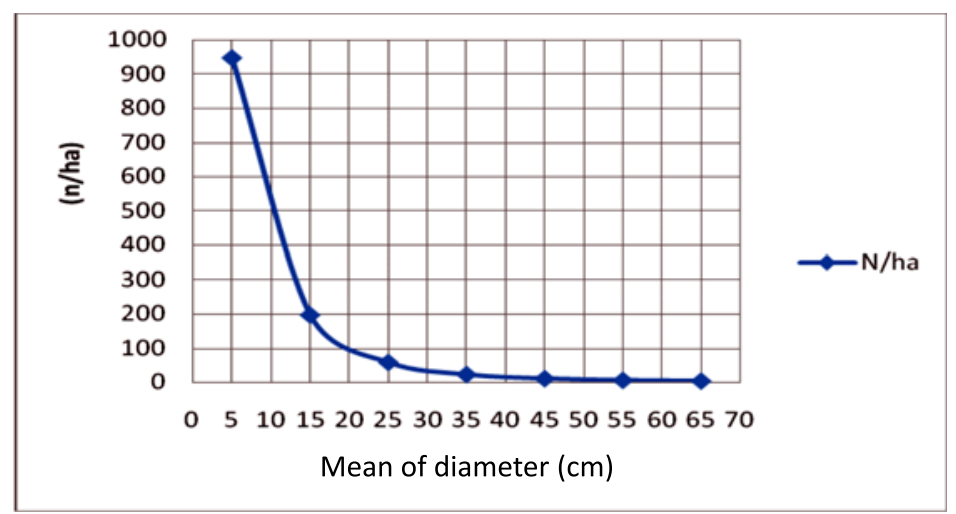

Figure 1. Function value charts diameter class distribution model mixed agroforestry patterns in Bulu. 


\section{Agroforestry MPTS Dominant Model}

MPTS had the tendency dominant pattern of a small land area, with an area of $<1,000$ $\mathrm{m}^{2}$. MPTS agroforestry patterns had a mean number of plants/ha higher than the other two clusters. A fairly steep slope does not reduce stand density, it can be seen from the mean diameter and standard deviation, which shows the mean diameter of the plant is very varied. It was greatly influenced composer composition stands dominated MPTS plants with a percentage of $>75 \%$. MPTS plants tend to be maintained despite having a relatively large diameter, due to the utilization of more toward the fruit produced.

MPTS dominant agroforestry patterns had a tendency to land with average characteristics of the stratum 1 land area $\left(<1,000 \mathrm{~m}^{2}\right.$ (, with a mean of $936.889 \mathrm{~m}^{2}$. MPTS dominant agroforestry patterns had a mean number of plants/ha of 1,555 with a slope of $32.77 \%$. The mean diameter of the pole and tree survival rate was $19.13 \mathrm{~cm}$ with a mean standard deviation of $7.9 \mathrm{~cm}$. The constituent of plant species composition was dominated by plants MPTS with a mean percentage of $77.79 \%$ while the mean percentage of $22.20 \%$ forest plants.

Table 2. Profile dry-field with MPTS dominant pattern of agroforestry in Bulu.

\begin{tabular}{|c|c|c|c|c|c|c|c|c|}
\hline \multicolumn{2}{|c|}{$\begin{array}{l}\text { Patterns of } \\
\text { Agroforestry }\end{array}$} & \multirow{2}{*}{$\begin{array}{c}\text { Broad } \\
\left(\mathrm{m}^{2}\right) \\
300\end{array}$} & \multirow{2}{*}{$\begin{array}{l}\text { N/ha } \\
975\end{array}$} & \multirow{2}{*}{$\begin{array}{c}\text { Slope } \\
(\%)\end{array}$} & \multirow{2}{*}{$\begin{array}{c}\begin{array}{c}\text { Diameter } \\
\text { Average } \\
(\mathrm{cm})\end{array} \\
16.517\end{array}$} & \multirow{2}{*}{$\begin{array}{c}\text { Diameter Standard } \\
\text { Deviation }(\mathrm{cm})\end{array}$} & \multirow{2}{*}{$\begin{array}{c}\text { MPTS } \\
(\%) \\
59.38 \%\end{array}$} & \multirow{2}{*}{$\begin{array}{c}\begin{array}{c}\text { Forestry } \\
\text { Plant } \\
(\%)\end{array} \\
5.71 \%\end{array}$} \\
\hline & Min & & & & & & & \\
\hline \multirow{2}{*}{$\begin{array}{l}\text { Dominant } \\
\text { MPTS }\end{array}$} & Max & 1,803 & 2,133 & $60.00 \%$ & 22.185 & 11.782 & $94.29 \%$ & $40.63 \%$ \\
\hline & Average & 936,889 & 1,555 & $32.78 \%$ & 19.133 & 7.907 & $77.80 \%$ & $22.20 \%$ \\
\hline
\end{tabular}

The pattern of dominant agroforestry MPTS had an $\mathrm{R}^{2}$ value of 0.770 . The value of the constant $\mathrm{K}$ of 3.155 and a constant value was -0.021 . So the equations exponential for MPTS dominant agroforestry models was:

$$
Y=3.155 \times 2.7128^{-0.021 X} \text { with } \mathrm{R}^{2}=0.770
$$

The agroforestry patterns MPTS has the composition and characteristics of the proximity structure slightly resembled that of a natural forest, in terms of the distribution of diameter classes compared with other agroforestry patterns in Bulu. The compositional structure shows similarities with the model of an uneven-aged forest that has characteristics resembling a natural forest indicated by the $\mathrm{R}^{2}$ value of 0.770 .

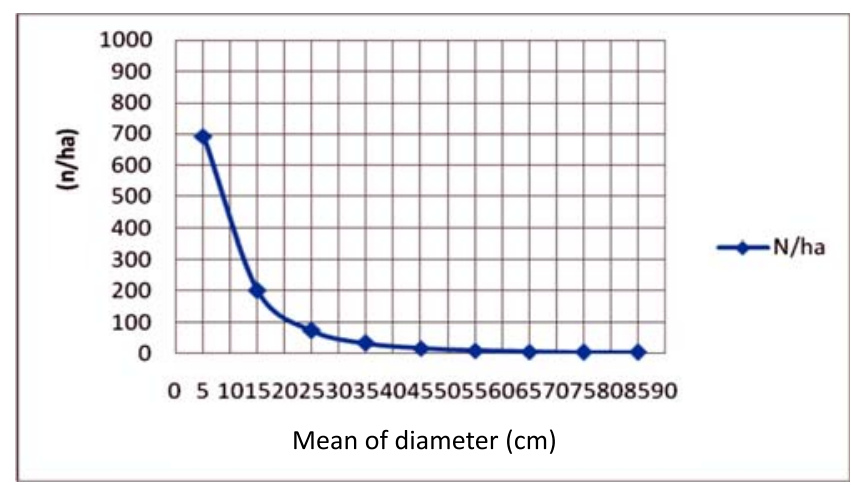

Figure 2. Function value charts diameter class distribution model agroforestry patterns dominant plant in Bulu MPTS 


\section{Agroforestry Forest Dominant Model}

The dominant agroforestry crop patterns had a tendency to land a relatively moderate in the range of $1,000 \mathrm{~m}^{2}-2,000 \mathrm{~m}^{2}$. Number of plants/ha was also relatively modest compared with the two other clusters. The low slope leads to the tendency of land use for forestry crops that can be seen from the percentage proportion of timber plants, which reached $66.21 \%$. The mean and standard deviation of the diameter indicated in cluster 3 is identical to the cultivation of intensive forestry supported by the relatively low percentage of slope of $19 \%$.

The dominant agroforestry crop patterns had a tendency to land with an area of land with average characteristics belonging to stratum $2\left(1,000 \mathrm{~m}^{2}-2,000 \mathrm{~m}^{2}\right)$, with a $1,004 \mathrm{~m}^{2}$ land area. The agroforestry crop pattern had a mean number of plants/ha of 1,286 rods of land with a slope of $19 \%$. The mean diameter of the pole and tree survival rate was $15.68 \mathrm{~cm}$ with a mean standard deviation of $5.36 \mathrm{~cm}$. The constituent of plant species composition was dominated by forest trees with a mean percentage of $66.21 \%$ while the mean percentage of $34.785 \%$ MPTS crop.

Table 3. Profile dry-field with a dominant pattern of forest trees in Bulu.

\begin{tabular}{|c|c|c|c|c|c|c|c|c|}
\hline \multicolumn{2}{|c|}{$\begin{array}{l}\text { Patterns of } \\
\text { Agroforestry }\end{array}$} & \multirow{2}{*}{$\begin{array}{c}\text { Broad } \\
\left(\mathrm{m}^{2}\right) \\
747\end{array}$} & \multirow{2}{*}{$\begin{array}{l}\text { N/ha } \\
481\end{array}$} & \multirow{2}{*}{$\begin{array}{c}\begin{array}{c}\text { Slope } \\
(\%)\end{array} \\
10.00 \%\end{array}$} & \multirow{2}{*}{$\begin{array}{c}\begin{array}{c}\text { Diameter } \\
\text { Average } \\
(\mathrm{cm})\end{array} \\
12.880\end{array}$} & \multirow{2}{*}{$\begin{array}{c}\text { Diameter } \\
\text { Standard } \\
\text { Deviation } \\
(\mathrm{cm}) \\
2.397\end{array}$} & \multirow{2}{*}{$\begin{array}{c}\text { MPTS } \\
(\%) \\
22.16 \%\end{array}$} & \multirow{2}{*}{$\begin{array}{c}\begin{array}{c}\text { Forestry } \\
\text { Plant } \\
(\%)\end{array} \\
42.34 \%\end{array}$} \\
\hline Dominant & Min & & & & & & & \\
\hline Forestry & Max & 1,330 & 1,744 & $35.00 \%$ & 17.977 & 7.538 & $57.66 \%$ & $77.84 \%$ \\
\hline Plant & Average & 1,004 & 1,286 & $19.00 \%$ & 15.683 & 5.368 & $34.79 \%$ & $65.21 \%$ \\
\hline
\end{tabular}

The agroforestry crops dominant pattern had an $R^{2}$ value of 0.706 . The value of the constant $\mathrm{K}$ of 3.182 and a constant value are -0.024 . So we get the equation for the model agroforestry exponential dominant forest trees:

$$
Y=3.182 \times 2.7128^{-0,024 X} \text { with } R^{2}=0.706
$$

Agroforestry pattern dominated forest plants have close structural composition and characteristics most resemble the natural forests, in terms of the distribution of diameter classes compared with other agroforestry patterns in Bulu. The compositional structure shows similarities to the model of an uneven-aged forest that has characteristics resembling a natural forest, as indicated by the $\mathrm{R}^{2}$ value of 0.706 .

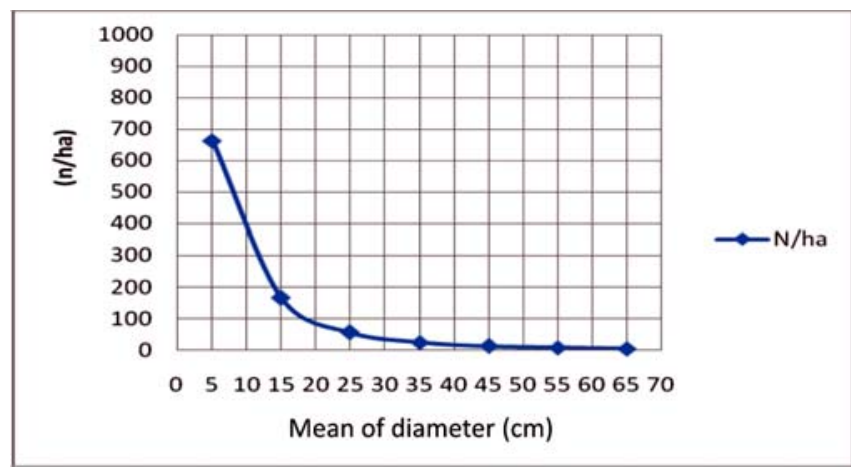

Figure 3. Function value charts diameter class distribution model agroforestry patterns dominant forest trees in Bulu. 


\section{The similarity between dry-field and natural forest}

The dry-field agroforestry systems in Bulu with various compositions have in common with the natural forest may be caused by the heterogeneous structure of the constituent tends to start its constituent species, tree height, plant age until canopy closure is affecting spaces grow in an area. The extent of the stratum varying also points to the value of the diversity. The value of this diversity can be used as a picture of the pattern of plant-based resources towards agroforestry and sustainable environment by considering three aspects, namely the availability of plant species diversity, conservation, and sustainable use. This factor in agroforestry systems is very instrumental in the success of agroforestry that will be applied to a field (Solikin, 2012). The results of the diversity of the three strata agroforestry land area is shown in Figure 4.

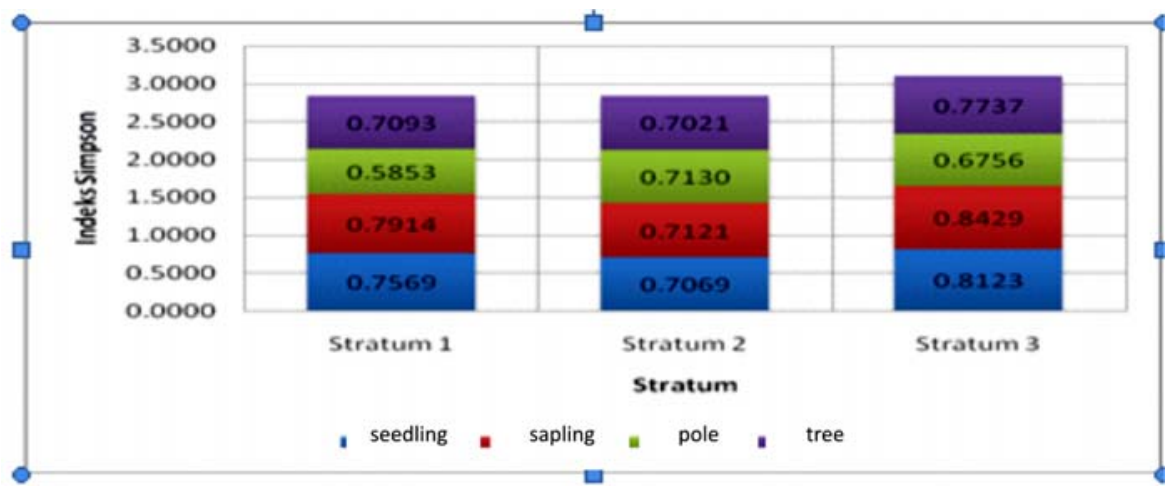

Figure 4. Diversity Index (Simpson) of each stratum in Bulu.

Stratum 3 is also described as a mixed agroforestry model with a high value of diversity, which can be found at the level of seedling and sapling life. Strata 1 and 2 are likely to have had the same relative diversity. The third stratum had a high diversity at the level of seedling. Diversity above 0.5 for each level is an indicator of the diversity of life that exceeds the criteria is (Dumbois and Ellenberg, 1974). It could be argued that all clusters have the characteristics of being diverse or more.

Stratum 3 had the highest Simpson index accumulated value at 3.1 for each level of plant life. The high diversity value indicates a lack of dominance of one crop compared with the other crops. At each stratum, mahogany plant dominance may be offset by other types of MPTS. Pole had the value of living a low Simpson index, because of mahogany plants and plant cloves dominating the living level.

Diversity was quite high; above the level where moderate $(>0.5)$ indicates a pattern in Bulu dry-field almost resembling a natural forest with high diversity. The high diversity of agroforestry patterns dry-field in Bulu demonstrates that ecological aspects can be run properly to ensure the future sustainability of good standing in order value of conservation and sustainable forest. From this, the pattern of agroforestry in Bulu can be used as a reference in the development of forest-based community forestry.

The model of regeneration in developing agroforestry patterns in Bulu shows proximity models with uneven-aged forest stands, as can be seen from the $R^{2}$ value above 0.7. Uneven-aged forest stands are one example where the natural forest, dry-field agroforestry subsystem in Bulu may be regarded as a miniature forest. This can be seen from the various 
constituent compositions in terms of constituent species of plants live up to the level that can at least describe the age of the plant. Agroforestry models dry-field proximity to natural forests can not be separated from the local knowledge of the existence of sustainable forests. The fundamental understanding of the society applied to the implementation of land use that is at least very similar to the conditions for sustainable forest. Kimmins et al. (2008) in Nair (2008) state that traditional knowledge associated with the birth of agroforestry practices that consider the social and environmental aspects.

\section{CONCLUSION}

The agroforestry dry-field in Bulu, Kulon Progo, which have a tendency to mix patterns (random mixture) showed that the structure and composition of the dry-field was similar to that of a natural forest. This is demonstrated by the high $R^{2}$ values $(>0.7)$ of the equation functions exponentially for each agroforestry model. Diversity was quite high; above the level where moderate $(>0.5)$ indicates a pattern in Bulu dry-field whose characteristics almost resemble a natural forest with a high diversity of each stratum.

\section{REFERENCE}

Awang, S. A., 2001. Gurat Hutan Rakyat di Kapur Selatan. Debut Press. Yogyakarta.

Darusman, D., and Hardjanto. 2006. Tinjauan Ekonomi Hutan Rakyat. PROSEDING Seminar Hasil Penelitian Hasil Hutan 2006: 4-13.

Hardiwinoto, S., S. Prianto, Adriana, Suginingsih, Budiadi, P. Suryanto, Widiyatno, S. Sabarnurdin, and G. Wibisono. 2011. Bahan Ajar Mata Kuliah Silvikultur. Fakultas Kehutanan UGM Yogyakarta.

Kangas, A., and M. Maltamo. 2006. Forest Inventory Methodology and Applications. Netherlands: Springer.

Khaerudin. 1999. Pembibitan Tanaman HTI. Penebar Swadaya: Jakarta.

Kumar, B.M., and P.K.R. Nair (eds). 2006. Tropical Homegardens: A time-tested example of sustainable agroforestry. Springer Science. Dordrecht: The Netherlands.

Mildaryani, W. 2012. Peranan Praktek Agroforestri terhadap Pendapatan dan Ketahanan

Pangan Masyarakat Kecamatan Samigaluh Kabupaten Kulonprogo. Proseding Seminar Nasional Pembaharuan Agroforestri Indonesia: Benteng Terakhir Kelestarian, Ketahanan Pangan, Kesehatan, dan Kemakmuran. Yogyakarta 29 Mei 2012 . Fakultas Kehutanan UGM (IMHERE) - INAFE - BPTA Kemenhut RI.

Mueller-Dumbois, D., and H. Ellenberg.1974. Aims and Methods of Vegetation Ecology. Wiley: New York

Nair, P.K.R. 1993. An introduction to Agroforestri. Kluwer, Dordrecht, The Netherlands

Nair, P.K.R. 2008. Toward Agroforestry Design An Ecological Approach. Springer Science + Business Media B.V: Florida

Simon, H. 2008. Pengelolaan Hutan Bersama Rakyat. Pustaka Pelajar: Yogyakarta.

Simon, H. 2010. Dinamika Hutan Rakyat di Indonesia. Pustaka Pelajar: Yogyakarta.

Solikin, 2012. Potensi keanekaragaman jenis tanaman dalam agroforestri: studi di Desa Galahreko Kabupaten Pasuruan. Proseding Seminar Nasional Pembaharuan Agroforestri Indonesia: Benteng Terakhir Kelestarian, Ketahanan Pangan, Kesehatan, 
dan Kemakmuran. Yogyakarta 29 Mei 2012. Fakultas Kehutanan UGM (IMHERE) - INAFE - BPTA Kemenhut RI.

Suryanto, P. 2012. Traditional Enrichment Planting in Agroforestry Marginal Land Gunung Kidul, Java, Indonesia. Journal of Sustainable Development Vol. 5, No. 2; February 2012 Published by Canadian Center of Science and Education 77.

Wicaksono, R. L., R.H. Purwanto, and D. Soeprijadi, D. 2012. Inventore Volume, Biomassa dan Karbon Bambu Petung (Dendrocalamus asper Backer) di Hutan Rakyat (Kasus di Dusun Ngandong, Desa Giri Kerto, Kec. Turi, Kab. Sleman, DIY). Proseding Seminar Nasional Pembaharuan Agroforestri Indonesia: Benteng Terakhir Kelestarian, Ketahanan Pangan, Kesehatan, dan Kemakmuran. Yogyakarta 29 Mei 2012 . Fakultas Kehutanan UGM (IMHERE) - INAFE - BPTA Kemenhut RI. 